\title{
The Number of the South African War (1899-1902) Concentration Camp Dead: Standard Stories, Superior Stories and a Forgotten Proto-Nationalist Research Investigation
}

\author{
by Liz Stanley and Helen Dampier \\ University of Edinburgh; Leeds Metropolitan University
}

Sociological Research Online 14(5)13

<http://www. socresonline.org.uk/14/5/13.html>

doi:10.5153/sro.2034

Received: 8 Oct 2009 Accepted: 19 Nov 2009 Published: 30 Nov 2009

\begin{abstract}
Tilly extols the power and compass of 'superior stories' compared with 'standard stories'. However, things are not always so clear cut, as the case study discussed here shows. A $1906-1914$ research investigation headed by P. L. A. Goldman, which has initially concerned with the enumeration and commemoration of the deaths of Boer combatants during the South African War (1899-1902), and later with the deaths of people in the concentration camps established in the commando phase of this war, is explored in detail using archived documents. Now largely forgotten, the investigation was part of a commemorative project which sought to replace competing stories about wartime events with one superior version, as seen from a proto-nationalist viewpoint. Goldman, the official in charge, responded to a range of methodological and practical difficulties in dealing with a huge amount of data received from a wide variety of sources, and eventually produced 'the number' as politically and organisationally required. However, another number of the South African War concentration camp dead - different from Goldman's, and also added up incorrectly - concurrently appeared on a national women's memorial, the Vrouemonument, and it is this which has resounded subsequently. The reasons are traced to the character of stories and their power, and the visibility of stories about the concentration camp deaths on the face of the Vrouemonument, but their anonymity within Goldman's production of 'the number'. Tilly's idea of an 'inbetween' approach to analysing stories by historical sociology is drawn on in exploring this.
\end{abstract}

\section{Keywords: Concentration Camps, South African War, Proto-Nationalism, Research Methodology, Stories, Historical Sociology, Archival Research, Charles Tilly}

\section{Introduction}

"If there is no general phenomenon of social change... What should we [historical sociologists] do? We should build concrete and historical analyses of the big structures and large processes that shape our era. The analyses should be concrete in having real times, places, and people as their referents and in testing [them]... against the experiences of real times, places and people. They should be historical in limiting their scope to an era... and in recognizing from the outset that time matters - that when things happen within a sequence affects how they happen... If a work is historical it need not be grand... A concrete, historical programme of inquiry must include work at the small scale and can well include our own time..." (Tilly 1984: 14)

1.1 How do 'big structures, large processes and huge comparisons' (Tilly 1984) come to have these evaluations attached to them? Is it that some social things just 'are' big, large and huge in a 'by nature' a priori way? Or is it a matter of social and political forces which eventuate in some things but not others being seen as such? This article traces the activities of a research investigation concerned initially with the enumeration and commemoration of the deaths of Boer combatants during the South African War (18991902) and later specifically with those of people dying in the concentration camps established in the commando phase of that war. ${ }^{[1]}$ This research investigation, now largely forgotten, was part of a highly politicised commemorative project which sought to replace the many competing and disagreeing stories and accounts of wartime events with one superior version, as seen from a proto-nationalist viewpoint and 
harnessed to the wider purpose of nation-building. Discussion is underpinned by our long-term research and accompanying publications on the records of the concentration system during the South African War and on the rise of proto-nationalism post-war (Dampier 2005a, 2005b, 2007, 2008, Dampier \& Stanley 2008, Stanley 2002a, 2002b, 2002c, 2006 [Click here for the Stanley 2006 book cover]; Stanley \& Dampier 2006a, 2006b, 2007; Stanley \& Wise 2006).

1.2 Charles Tilly $(1999,2003)$ has distinguished between what he calls standard stories, having limited characters, plots and explanatory power, and superior stories which work with complexities and produce convincing causal explanations, and he has also suggested ways in which the standard is made more complex and the superior may have deficiencies. In the spirit of the wider intellectual project in historical sociology that the epigraph to this article inscribes, although working in the opposite direction from the macro-level analysis that Tilly himself provides, we present a small-scale analysis of changes occurring in South Africa post-1902 against the backdrop of developments in big structures, including the development of capitalism, imperialism, mechanisation, urbanisation, and in large processes, including the shift from emergent proto-nationalism to nationalism and a more rigidly racially segregated society. We do so through a case study of a research investigation that was caught up in, created and shaped by the immediacy of such changes, in doing so endeavouring to build the kind of analysis Tilly calls for.

1.3 As part of this, we shall explore the complexities of both kinds of stories Tilly identified, and refer to the in-between ones he also alludes to. So-called standard stories are often not so standard; and in the case study we discuss they took on the power and clout of superior explanations because over time they displaced the superior story produced by the research investigation, and became 'how it was' and a statement of seemingly incontrovertible fact. Edward Thompson (1968: 13) coined the phrase the enormous condescension of posterity' to characterise the Whiggish dismissal of past understandings and explanations of social events by historians who treat their hindsight knowledge as evidence of superior understanding over those who lived through turbulent changes. In relation to the number of the South African War concentration camp dead', however, the converse can be observed, in the form of an enormous deference from posterity. Here, as time passed, the loss of direct knowledge of wartime complexities and political divisions, together with the powerful articulation and re-articulation of the standard story at critical political junctures subsequently, eventuated in the valorisation of one highly partial account of the events of this war and the non-combatant deaths occurring during it, an account which was produced as part of the proto-nationalist platform but with these origins now forgotten.

1.4 We detail the working process of the research investigation referred to, which was carried out between 1906 and early 1914. Its purpose was to enumerate the private troubles of the many war deaths in the framework provided by the proto-nationalist project of the day, in characterising the war in a particular way, in fashioning public memory of wartime events from this particular perspective, and relatedly in collectivising and homogenising the meaning and character of the Boer deaths that occurred. ${ }^{[2]}$ Specifically, its job was to produce 'the number' - that is, an accurate total of those who had died. The investigation was headed by an official, P. L. A. Goldman, who for most of its duration acted as a private secretary to Louis Botha, the head of one of the formerly independent Boer Republics, the Transvaal, annexed by Britain during the course of the war. Goldman's task in fact evolved over the time the investigation lasted, for political reasons connected with divisions within the proto-nationalist ranks, and in particular between the political leaders of the Transvaal and the other annexed former Boer Republic, the Orange Free State. ${ }^{[3]}$

1.5 Following elections, 'Responsible Government' came in 1907 for the Transvaal, with Botha and Smuts heading Het Volk, and in 1908 in the Free State with an Orangia Unie government. The context was one of wartime great dissention within the Boer populations, with many Boer people supporting Britain or rejecting ascendant proto-nationalism, with wartime political and other differences between the Transvaal and Free State persisting and indeed exacerbated in the post-war period. Goldman's work was under-written by the Transvaal. Nevertheless, as will become apparent, the enumerative and commemorative project was to a large extent driven by the Free State and its rather different ideas about who was to be commemorated and how; and also by another separate process, in which proto-nationalist cultural brokers from women's organisations stimulated and orchestrated the production and publication of Boer women's testimonies of their wartime experiences. ${ }^{[4]}$

1.6 The documents generated by Goldman's investigation remained intact after it was wound up in early 1914 until they came under the purview of the Transvaal archives section of the National Archives Repository in Pretoria, South Africa, in 1932 (although their whereabouts from 1914 until then is unknown). A full inventory description and handlist of contents of the collection, T1, was produced in 1959 by Arthur Davey and is still that used by contemporary researchers, while the collection itself is known as RS Goldman. ${ }^{[5]}$ We now explore Goldman's investigation and relate its focuses and developments to the wider political framework. In doing so, we provide jpegs of original documents and other sources significant to the argument we present. Most of the collection's contents and its Inventory are in various versions of Afrikaans as this was developed as a language over the period between the first document in the collection, dated early 1906, and the production of the inventory in 1959; therefore we supply translations where appropriate. ${ }^{[6]}$

\section{The Goldman collection in theory and practice}

2.1 The 1959 Inventory of the collection of '...the official charged with collection of statistics of deaths in the Republican forces and amongst the civilian population $1889-1902^{[7]}$ sets out an ordered archival domain, seemingly reflecting a clear originating aim and context of activity: collecting statistics, concerning the period 1899-1902 (implicitly, during the South African War), of two kinds of deaths, those of (again implicitly) those who fought and those who were civilians. The official in question, Goldman, is described in the introductory part of the Inventory (T1: i-ix) as having been charged with a clear explicit and 
unchanging purpose, with his working methods arising directly from this, and which resulted in him achieving the originating aim of producing 'the facts' in a statistical sense, concerning Boer deaths during the South African War. The Inventory also describes the collection as having four clearly distinguished sections. These are of incoming items, followed by outgoing items, followed by provisional data, eventuating in final data, implying a linear development from the first through to the fourth section. Within this classificatory framework, the collection is populated by 34 main Volumes (Bands), with clear summary descriptions of the contents of each Volume provided in the listing part of the Inventory. The Inventory states that this was the actual organisational order of the composing documents as these were received by the Transvaal State Archive component of the National Archives Repository in 1959. There is a hint of greater complexity, with an in-passing comment that additional organisational documents were interleaved at appropriate points within the order of this domain (T1: vii), although the tenor of this comment implies that order simply prevailed, with these extras not so much assimilated as finally put into their proper places.

2.2 When the actual contents of the Volumes are examined, however, this shows something rather different from the tidy and carefully delineated archival domain as set out in the T1 Inventory. Beneath this collection framework is a complex, messier more fragmentary set of documents, inscribing aspects of a very complicated array of working practices which did not always result in full organisational records of an 'everything to hand and everything in its proper place' kind. There are always, drawing on Garfinkel (1967: 186-207), good organisational reasons for bad organisational records, and the organisational structure presided over by Goldman is no exception to this general sociological observation about the character of organisational structures and practices. Each Volume has a clear title or summary description of its contents in the Inventory (T1:1-4), but actually the contents are very mixed. The descriptions of the Volumes invoke documents, or a letter-book, or registers, or summaries and lists; but within is a greater complexity that always exceeds the descriptor: letters in and letter-copies out are, for instance, annotated and amended, while memos jostle with lists of places jostle with single words or names on scraps of paper jostle with memos and a writer's (name not attributed) notes to self. The stated content is then just one kind of document, not necessarily the dominant one, among the array. Some examples from across the classificatory sections will help demonstrate this plenitude.

2.3 Volume 4 is located within 'A. Incoming items' (Inkomende stukke) and labelled as 'United Churches' (Verenigde Kerke). However, many of its contents are actually outgoing items from Goldman, requesting information or asking for its corroboration; and while it does contain letters and lists of information sent to Goldman by dominees of the main churches or kerks (the NGK and the $\mathrm{NH}$ of $\mathrm{GK}^{[8]}$ ), it contains many more lists by Goldman. These include lists of names of dominees and the districts they worked in, lists of places in South Africa but no indication of the purpose of these, lists of people's names with numbers next to each but who these people are or what the figures represent not stated. For instance, many, even most, documents in Volume 4 (and in most other volumes) are not dated. Also, more than one handwriting appears on the documents. It may be presumed that Goldman's is the majority handwriting, which is also that which makes momentous paper-decisions such as the excision of names and the editing of documents, but the names of the sub-officials who assisted him are nowhere recorded although the different handwritings attest to their organisational presence.

2.4 Volume 15 is the sole item composing the 'B. Incoming items' (Uitgaande stukke) part of the collection and is Goldman's letter-book, kept throughout the process from early 1906 until his office was wound up in early 1914. Formally speaking a book of letters sent to Goldman, these are at points heavily annotated and added to. These emendations are the basis of replies Goldman intended to make to the correspondent in question, and/or key points he drew from or disagreed with in the letter in question. Consequently, although apparently neat and contained, the additions to these incoming letters means they flow into the other classificatory headings and so challenge the boundaries of what a letter 'is'.

2.5 Volumes 20 to 34 compose the 'D. Final data' (Finale gegewens) component of the classification, although in fact the documents within them have a greater degree of provisionality than finality. Thus, for example, the alphabetical lists of Transvaal citizens who died in the concentration camps established during the South African War in Volumes 25-27 contain amendments, insertions and deletions, as do those for the Free State (29-30) and the Cape and Natal (31). And while it might be supposed that the lists for each of the annexed provinces (Volumes 25-31) were succeeded by those containing the overall alphabetical lists (Volumes 32-34), the latter also feature amendments, insertions and deletions and in doing so suggest a process still in motion rather than its conclusive end-point.

2.6 Volume 16 is part of the 'C. Provisional data' (Voorlopige gegewens) classificatory component and is summarised as 'Notes and summaries' (Aantekeninge en opsommings). It is composed by 95 documents ranging from small scraps of paper to several sheets of typed cyclostyled letter-copies. Here too scraps of paper with single words or brief now-unintelligible notes jostle with formal documents, with letters appealing for information, with incoming lists, and with Goldman's lists of people and places and numbers. Again, most items herein are undated; and while one handwriting predominates, others too are present. The documents in Volume 16 contain a mixture of incoming and outgoing items, and while it also contains provisional data, a sub-set (RS16: ff75-89) is more accurately described as final data - more final, in fact, than anything in the Volumes so labelled. These are numerical summaries of the apparently 'final data' in Volumes 32 to 34, while Volume 16 also contains the tables which are the culmination of the process Goldman engaged in and which provide 'the numbers' of the dead. However, as we go on to discuss, these deaths are not quite as stated in the Inventory title noted earlier ('deaths in the Republican forces and amongst civilians'), but deaths having occurred specifically in the concentration camps, and anyway the contents of Volumes 32 to 34 are a partial compilation of other files and data from other Volumes. Also, over the period of research and data collection Goldman engaged in, the key aim in terms of the production of the statistics had changed. 
3.1 Goldman was appointed in January 1906 at the request of Louis Botha, leader of Het Volk and clearly prime minister of the Transvaal in waiting. The British Lieutenant-General's Office, via its chief legal officer Richard Solomon, agreed to pay Goldman's salary and his task, noted earlier, as initially set out was to provide accurate statistics of the burghers (Boer men on commando) who had died in combat or of wounds during the South African War (RS1: 26 January 1906). Relatedly, policies were instituted for the remains of men who had been buried where they were killed to be 'brought in' to local villages and towns for burial and memorialisation (RS7: ff8-9 May 1906), and there is clear evidence of a concerted Transvaal policy of repatriation, enumeration and commemoration of the fighting burghers. ${ }^{[9]}$

3.2 The Inventory indicates a number of orderly successive phases to Goldman's work (T1: vi-vii): the Red Cross was approached for information about the fallen burghers, which it states was so good in quality that he then was able to investigate the deaths in the concentration camps; his first investigations between 1906 and 1908 concerned the situation in the Transvaal; there was a lull when Goldman was appointed a member of the War Casualties and Injuries Commission; and then between 1910 and 1912, he worked on producing the Free State, Cape and Natal statistics. This is a description of a classic linear research investigation, but the detail contained in documents across the collection shows it is inaccurate and misleading.

3.3 The Red Cross was approached, but in fact had only partial information about the burghers and suggested other possible sources, including Goldman himself regarding the work he did during the war in trying to trace missing people (RS 2: f2, 27 September 1906). Also, there was actually no intention at first from Botha or Goldman to enumerate and commemorate the deaths of the people, mainly women and children, who had died in the concentration camps. This was instead driven by two other separate dynamics: The first is that after 1902 many local memorial committees came into being, to an important extent encouraged and propelled by the rapid post-war growth of women's groups and organisations, and were concerned with naming and commemorating those who had died in the camps, in which many of them had lived and lost family members. In many cases, this work was completed by around 1908 and gave rise to local enumerations of deaths, to many mothers' memorials to their dead children, and also linked to published testimonies which were circulated in women's organisations and also in explicitly protonationalist cultural contexts such as newspapers and magazines promoting the development of Afrikaans as a language. ${ }^{[10]}$ The second is that considerable differences existed between the new political elite of the Transvaal, and the older one of the Orange Free State represented by ex-President Steyn and his followers. Steyn was adept at political manoeuvring and also had a strong moral sense of where the brunt of the war' (Hobhouse 1902) had fallen, both of which led him to want the deaths of the women and children who died to be enumerated and commemorated. He began discussions on this in 1905, establishing a Free State coordinating committee for such in February 1907 (Stanley 2006: 58-60) with the explicit intention that there should be a public monument to 'capture the public imagination'. The committee instituted an appeal for donations, however small, to built what became known as the Vrouemonument or Women's Monument. ${ }^{[11]}$ It also established an investigatory process in which the Free State field-cornets (veldkornets ${ }^{[12]}$ ) conducted detailed enumerations of deaths and recorded survey sheets of these in the local areas of their jurisdiction. Then, following this (rather than preceding it, as the Inventory states), a similar enumerative process was established in the Transvaal via Goldman.

3.4 Also, even earlier, an Ecclesiastical Commission (Kerklijke Commissie) was founded in December 1903 by the various Dutch Reform Kerks, and this agreed a process by which 'one thorough statistic' of those who had died should be compiled (RS4: f4, February 1904). Its enumeration process was already well underway when Goldman started work, and locally, through its kerk elders or predikants, it often cooperated with the Memorial Committees. And although there may have been a lull in Goldman's activities (the paucity of dated documents makes this difficult to establish) from 1910 to 1912, there was none in the activities of these other organisations and enumerative processes. Lastly here, Goldman's working procedure was not temporally sharply demarcated in the way suggested by the Inventory - he appears to have continued working on quality-checking and reconciling information through to 1913, with counts and the number' produced only in December that year, as we discuss later.

3.5 Over a lengthy period, sometimes with considerable delays (and also with some field-cornets failing to supply information even after reminders), Goldman received huge numbers of enumerations of those who had died', provided to him in a number of formats from a variety of sources. The predikants and the fieldcornets were requested to reconcile their respective lists (RS16: ff41-43), because of the importance of these to Goldman's investigation. Notices of (some but not all) deaths in the (British) Government Gazette and other semi/official papers were collected and used. Graveyard Registers and Registers of Deaths kept by the 'official' dominee employed in most camps were obtained (RS16: f34), with their listings treated as semi-official records. Also, the individual camp registers of arrivals, sickness, births and deaths and outwards movements of people, underpinned by daily and weekly 'returns' of information made by each camp to British coordinating headquarters in Pretoria (Transvaal) or Bloemfontein (Free State), were somewhat patchily and late on in the process commandeered from the various places they were stored (RS16: ff35-36; RS16: f52). These were then used in a perhaps surprisingly residual ad hoc way by Goldman, as an add-on source to the others rather than one he systematically combed through and took names and information from. This was in part because, until well on in his work, Goldman did not have an accurate list of different kinds of camps, as the very large number of variant and disagreeing lists of these scattered through the Volumes amply shows, and so was unable to call up all the files and registers he might have wanted. In addition, the most extensive of these records were the daily, weekly and monthly 'returns' made by all the camps to their relevant headquarters in either Pretoria or Bloemfontein, a huge volume of data, and Goldman's use - or rather non-use - of such returns is notable. ${ }^{[13]}$

3.6 Many handwritten and typed lists of camps exist across the Volumes, most of them listing large numbers of places and with no understanding of the difference between temporary laagers and 'permanent' camps; between prisoner of war camps, relief camps, and concentration camps; and between permanent 
camps, and camps which removed en masse from one place to another with the same population of inhabitants. This reflected the complicated wartime circumstances 'on the ground', but also that neither Goldman nor other Transvaal officials initially knew where the camp records had been sent at the end of the war and had to find this out and obtain them, and thus there were attendant delays and also consequences for sometimes under- but more often over-counts of populations and of deaths. Later in the investigation Goldman became aware of this (RS16: f93), and also that there were whole sets of concentration camp registers (for Kroonstad camp) and part-sets of registers (for example, Bethulie and Springfontein camps) that were missing. In the former case, this was because of accidental loss when the registers were being brought across country; in the latter and other similar instances, it was because other people had earlier removed and not replaced files and registers, with some of these in private collections which later found their way into the state archive system. ${ }^{[14]}$

3.7 Overall, however, it is clear that Goldman prioritised lists and information received from 'het volk', from Boer sources rather than 'official' British ones, so his base data came from, firstly, the originally verbal reports made to the field-cornets and written out by them usually in summary form on cyclostyled enumeration forms; and secondly, from the records kept by, primarily, the NGK rather than the in some areas much larger NH of GK. This latter introduced (perhaps unwittingly, although this cannot be known for certain) two sources of systematic bias into the data. One is that these records concerned the NGK dominees 'parishioners' only, not members of other kerks or of none in the camps; and the other is that these kerk sources also largely (but not invariably) omitted the deaths of unbaptised children and those who were stillborn to even NGK mothers. However, within limits, Goldman carried out fairly extensive checks on the lists of names and claimed deaths he received from these sources but did so in a very patchy way, as some comments about how he responded to the lists from the two groups of field-cornets will indicate.

3.8 There are six volumes of Free State field-cornet returns, two for the Transvaal. The Free State process appears to have been more extensive and begun earlier, with the enumerations generally but not universally made on a cyclostyled form (for example, RS8: f4), with highly variant lists and also other kinds of information sent to Goldman. What resulted from the Transvaal field-cornets is similar in its variability, with the formalised enumerations of men, women and children on the official form co-existing with all manner and kinds of lists, such messy scrawled list of men's names with no other information recorded (see, for instance, RS5: f74, together with neat detailed lists (RS6: f29), together with dense paragraphs about people and families (RS6: ff52-54).

3.9 The format and quality of what resulted in relation to what was requested is extremely varied, then. There were many field-cornets involved in both the Free State and Transvaal and their interpretation and execution of their task differed greatly. Some treated the recording form as a 'scientific instrument' and recorded precisely the information requested in a highly consistent way; some ignored the form and its boxes and provided in effect narratives of people and their deathss some were barely literate and recorded only the briefest of information; and many were inconsistent and recorded in a variety of ways as they went house to house and farm to farm.

3.10 Goldman worked through the many thousands of enumerations that resulted. In relation to the Free State field-cornet forms, in many cases he crossed out names where deaths clearly had not occurred during the war years, nor in warfare nor a concentration camp (eg. RS8, the Bethlehem District enumeration forms). However, this was not entirely consistently done and in some cases 'non-relevant' deaths remain included (see for instance RS8, Kestell District enumeration forms, where a death in India is retained; RS13: f17, the Thaba' Nchu District enumeration forms, where someone who has died from sickness in their home is excluded from the right deaths' while someone who died in the same month and year from the same sickness is included because dying in a camp; and RS8: f94, Bloemfontein District enumeration forms, where deaths are included even though all that is recorded is the name with the date and place 'unknown' (onbekend)). However, although Goldman had a checking policy, this operated with considerable variability concerning the field-cornet data, and also regarding what seems to be entirely unchecked overlaps between this and his other sources. Thus, for example, there is little sign that the field-cornets and the kerk predikants did actually reconcile their sets of information, every sign these were sent to Goldman piecemeal (rather than as sets), with neither any internal, nor any cross-set, reconciliation of differences and overlaps having taken place.

3.11 Implicit in the above discussion is that a shift had occurred in the focus of Goldman's investigations, almost certainly because of enumerative and commemorative concerns in the Free State and more widely from women's organisations. Its occurrence can be indicated by reference to an undated draft letter (in English, with another version in Dutch) from Goldman to the Secretary to the Administrator of the Free Sate, writing that the field-cornets, by reference to the authority of the Minister of Agriculture, could carry out house to house and farm to farm visits to record information (RS16: f39):

\section{"... the Right Honble the Minister for Agriculture has now approved of the suggestion

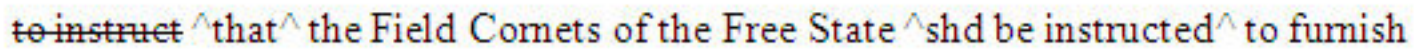 \\ Lists of the names of those persons who fell and died during the war $\wedge$ and of those who died in the Concentration Camps.'}

3.12 The entire draft has been multiply amended in pencil, while in black ink and seemingly inserted last is the addition shown above, of ' $\wedge$ and those who died in the concentration camps ${ }^{\wedge}$. However, this represents a transition and not an end point - from having this 'and' status in relation to the burgher deaths in just the 
Free State, by the point Goldman received the detailed listings from the field-cornets and worked through them, the focus had moved specifically to the concentration camp deaths in both the Free State and the Transvaal, with his quality checks removing not only incompletely attributed and uncertain deaths but also many of those which had occurred outside of the camps, in people's homes, in combat and POW camps.

3.13 The data collection and quality checking issues Goldman had to deal with which we have commented on thus far involved him trying, in a patchy way, to ensure some consistency and accuracy regarding the lists of data he received. There were, however, more structural issues in how Goldman worked that adversely impacted on his calculation of totals and types of death and thus on 'the number' of the concentration camp dead he arrived at, and it is important to recognise these.

3.14 The procedure Goldman engaged in involved the names on the lists of enumerations sent to him then being transferred from one recording medium (lists, enumeration forms), to another (alphabeticallyorganised registers for each of the provinces), to another (lists of names of the dead per province), to another (the overall alphabetical list of the dead), to summary counts, to final tables. Across these multiple transferrals, inevitably mistakes were made, omissions occurred, duplicated entries were not detected, in part of course because of the sheer scale at which Goldman was working. However, at various points in his working process, Goldman seemingly became aware of such slippages and devised ad hoc ways of rectifying them by, for instance, distributing a 'find' of tens or even hundreds of people across the category groups using a ratio based on the distribution before he had discovered the slippage. Another interesting feature is that, during the later stage of producing summary counts, Goldman counted adult men and women differently from children. Counts of children were made in two rows (presumptively, of boys, then girls) per page of information, with the two columns representing Goldman working through all the pages of lists; and these counts are in ordinal numerical form (e.g. 27 and 29; 43 and 41; see RS 16: f84 for the Free State). But, perhaps to ensure that the counts of adults were not muddled with those of children, Goldman counted adults in groups of five, but in two ways: the first is $\mathrm{HWH}$ and the second is $\mathrm{WH}$, but with both representing the number 5 . Mistakes crept in here in producing totals per page of counts at a later stage in the process, for sometimes $\mathrm{WWH}$ seems to have been counted as 5 but also sometimes as 6 .

3.15 What has to be remembered about this is that, with just paper and pen or pencil, Goldman was working with many thousands of items of information received from multiple sources in variant forms and did so over a long period of investigation. Clearly, there were good organisational reasons for ad hoc organisational practices that were unable to pick up every such issue. We are not suggesting here that, with other better means of collection and analysis and by collecting more or different of the data available, Goldman would have produced the number' accurately - we are quite clear that no full accurate data exists for anyone to do this, either at the time, or now with computer-facilitated methods at a researcher's disposal, and that such a task is intellectually futile because the 'bad organisational records' produced for very good organisational reasons cannot have their flaws removed, their absences filled, their inaccuracies rectified. Relatedly, while the wartime and its complicated and always changing circumstances inevitably resulted in 'imperfect' data in an organisational sense, there were also additional issues which Goldman was perhaps unaware of the methodological import of and their consequence for 'the number' arrived at.

3.16 One methodological matter of considerable significance for the statistic Goldman was attempting to produce concerns the age at which someone stopped being a child and became an adult man or woman around how this had been defined within the official British system of recording information (and used regarding the allocation of rations in the camps). In fact, for most of the duration of the war, the Transvaal used the twelfth birthday and the Free State the sixteenth for this purpose, producing a very different shape to the demographics provided by each headquarters from informational returns received from the individual camps under their jurisdiction (Stanley 2006: 134-161. [15] These birthdays were, however, the cut-off points (eg. after 15, someone stopped being a child for the Free State headquarters), while Goldman both assumed the age was universally 16, and that this included people throughout their sixteenth year and so everybody who was less than 17. This is clearly a huge investigatory 'mistake', for the young massively predominated in the camp populations, but it was particularly important for Goldman and the political leaders he worked for. This was because of the political need to represent 'het volk', 'the people' in a nationalist sense, as having been to a man, woman and child always united in opposition to the British, and relatedly to show that males of fighting age were not in the camps (and so surrenders to and joiners of the British side) but on commando. The effect of how the age division was interpreted was to under-count males of commando age by over-counting the gender-undifferentiated 'children' (kinders) in the camp populations, and as we shall indicate later, doing so was probably a deliberate decision.

3.17 A second important methodological issue is that, while the originating lists of the dead and then the registers these were transferred to may have contained full information (name, date and place of death, source of information), this was not necessarily complete information. Thus, Standerton could be the town as well as the camp, for instance, and which it was in Goldman's terms made a difference concerning whether a death was to be counted in or out, and mainly he seems to have assumed that, unless otherwise detailed, the places of deaths were the camps. The most widespread incompleteness in the enumerations, however, concerns the use of initials rather than full names, so that Goldman was often unaware whether a listed death was that of a man or woman, boy or girl. These case were totalled separately as 'dubious' (dubiens) in the case of people aged 17 and older. In political terms, as commented above, the numbers of adult men in particular in the camp system mattered a lot politically, so Goldman distributed his 'dubious' using a ratio derived from the proportions of deaths known to be of adult males and females on the page concerned (see for instance RS16: f78, where, from a ratio of $7 \frac{1}{2}: 19$, he redistributed 188 'dubious' deaths as being those of 52 men and 133 women). In many ways this was a sensible, and in methodological terms defensible, strategy. However, women were considerably more likely to die than men in the camps, so the paradoxical effect is that Goldman's strategy here in fact over-counted males aged 17 and over.

3.18 It is also worth noting that Goldman did not devise a 'dubious' category for his counts of children: he simply recorded them all as either boys or girls, although many had only initials or 'baby' (baba) attached to 
their surnames. This was most likely because in the political sense indicated above it did not matter to him and his task-masters what sex the children were - what mattered was that they were children and not adults. However, it is interesting that, within a working practice otherwise so precise, Goldman did this, and it strongly confirms that this was a political project carried out for political purposes, not a scientific investigation engaged in for its own sake.

3.19 A third significant methodological issue, which again produced systematic effects, concerns the duplications inevitably present with using a number of overlapping but not coterminous sources, although concerning the same population of people. There are extensive indications across the two sets of fieldcornet enumerations of the limitations of Goldman's quality checks on incoming data with regard to this, so that what are highly likely to be the same people, but with only small variations in formation, appear in multiple entries. If, for instance, Coetzee, Coetsee, Coetzer, Coetser, Coetsen, Kotze, Kotzee, are not cross-checked against each other, although otherwise exactly the same information may have been recorded, then the effect is considerable because introducing a major but unpredictable source of overcounting deaths. ${ }^{[16]}$ However, this is an over-counting which could only be picked up and reconciled by checking every enumeration of every death against every other - or perhaps of using one data source only as the base and comparing the others against this. There is no sign Goldman did either.

\section{Goldman's method for producing 'the number'}

4.1 Goldman's specific methods, in the sense of how he worked the returned enumerations of deaths after the various quality checks had been carried out, are not entirely recoverable. This is not surprising: the complete and entire records of a complex organisational structure, or even a simple organisational structure carrying out a complicated set of activities involving an array of external groups and organisations, as with Goldman and his sub-officials, rarely survive. Parts of the process experience inevitable humdrum kinds of attrition - the piece of paper crumpled and thrown away, the misplaced or misfiled document, the lost file in an office move. However, Goldman's detailed working method can be largely pieced together from the remaining paper-trails and consists of the following, which seem to have been successive activities (again, caution is required given the relatively small number of dated documents):

- Following repeated requests and a variety of persuasions, Goldman received enumerations from (all? most? this is impossible to tell) of the field-cornets and also both lists and also registers of various kinds from the dominees and their predikants, and he also sought information from a variety of other sources outlined earlier. As detailed above, this information was worked through and, certainly regarding that from the Transvaal and Free State field-cornets, quality checks were carried out. Also, either at this stage or more likely later in the process (see below), Goldman will have had to resolve conflicting information and otherwise reconcile conflicts between the different data sources he was employing.

- The incoming enumerations were transferred to registers, for the Transvaal, the Free State, and a combined one for the Cape and Natal (RS17, 18, 19). These registers have alphabetical sections, with 'the names of the dead', date and place of death and source of information all recorded by surname in an 'as it came to hand' way. Consequently within each section for each letter of the alphabet, while the surnames all begin with that letter, strict alphabetical order thereafter does not apply (so that Zijl may follow and not precede Zyl, for instance). However, not every name to be found on a list can be found in one of the registers and not all names in a register will be found on an enumerative list - each underceeds and exceeds the other. Also there are names on these lists and in the registers which cannot be found on memorials listing the dead in the relevant camp Gardens of Remembrance (Gedenktuine; see here Stanley 2006, Chapter 8); the 'national' process being operated by Goldman was not coterminous with the commemorative process engaged in by the local Monument Committees or by the Ecclesiastical Commission. There are also, as noted above, clear indications of the limitations of Goldman's quality checks on incoming items with regard to duplicated enumerations of deaths.

- The broadly alphabetical enumerations in the registers were turned into new listings (RS20 - RS31). These are organised on the basis of classifying types of persons - Republican forces and citizens (non-combatant men, women and children) - and for the latter, also their places of deaths in the sense of whether these were in the Transvaal, Free State, Cape or Natal camps. Enumerations of 'Republican deaths' were also produced and this information is contained in these registers, although from what source or sources Goldman received this data cannot now be traced.

- These alphabetical lists distinguishing 'dead citizens' (gesneuwelde burgers) from 'Republican forces' (Republikeinse magte) provided the source of the counts of deaths which Goldman made. In making these, Goldman worked by counting the data in sections: he made four sheets of counts for the Transvaal deaths (RS16: ff79-82), three for the OVS (RS16: ff84-86) and one for the Cape and Natal ones (RS16: f87), presumably to make the process of adding up a more manageable one.

- Rough tables were produced which feature the summary numbers per sheet of counts. For the Transvaal, there are four lines of sub-totals (RS16: f78), for the Free State there are three lines of sub-totals (RS16: f83), and the Cape and Natal have one line of sub-totals (RS16: f87).

- These sub-totals were brought together on a summary sheet and added in two different ways by Goldman (RS16: f89). The first time he added the sub-totals per lines of counts. Then after an excised cross-count, he did so using the numbers per province, with the latter showing him that his previous count was incorrect by some thousands.

- There is a 'Total Summary' (Algeheele Recapitulation) sheet which has inscribed on it the numbers 
of concentration camp deaths per province (i.e. with the four or three, or one, lines of counts amalgamated) and the overall total. This is in pen and is a semi-final stage of working the numbers into totals and one overall 'the number' (RS16: $\mathrm{f77}$ ). It is of the total instances of deaths in concentration camps: 'Totaal ?gebale algeheiloverlede in kampe 27927.

- A typed version of the 'Total summary' in the form of a cyclostyled table of state or province totals and a grand total is dated 8 December 1913 (RS16: f75). This was eight days before the unveiling of the Vrouemonument in Bloemfontein, which has the number' prominently inscribed on its dedicatory front - but this, however, is a different number from what appears on Goldman's final table of the number', as discussed later. Goldman's 'Total Summary' has two typing mistakes in the numbers given, although these have been hand-corrected and a request for it to be retyped and six copies made is written on.

- Also dated 8 December 1913, there is what appears to be the number' in a final tabulated form (RS16: f76), without any numerical typos. Its caption has been re-written in English and the typed 'deaths' has been changed to 'succumbed', a toned down word by comparison. The text for the various sub-totals has also been translated into English, and in both languages is the rather startling: 'Men above 16 years of age', and 'children under 16 years of age' (Mannen boven de 16 jaar, and kinderen onder de 16 jaar). However, this not how Goldman calculated the numbers, as detailed above, and was written thus perhaps because he had realised or someone had brought to his attention the mistake built into his figures. What has been done here is simply that the descriptor has been changed - the momentous mistake is allowed to stand in terms of the actual counts, and it is simply covered over, with the numbers unchanged. This table has been signed off as final with 'PLAG' and '8.12.13', while Goldman has also written onto this sheet the numbers of 'war casualties', that is, of burghers on commando. Their total is 6189; this number includes those who died of sickness (924), in accidents (157), and of POWs (this would have been mainly illnesses or age), 1118. There were 3990 killed in action.

\section{'The number', which number?}

5.1 Is Goldman's statistic of the total deaths in the concentration camps of the South African War accurate? ${ }^{[17]}$ Is 27,927 how many people died? Within the limits we have discussed, particularly limits of a political kind, Goldman did his best to be consistent and accurate, although his practices were patchy, and his working process attempted to be careful in working with huge quantities of very varied data. At the same time, the sources he worked with, and his prioritisation of unreconciled and closely but not entirely overlapping data, introduced the systematic problems discussed earlier. There are also issues, as discussed, concerning the manipulation of the age division between male adults and children, and an equally manipulative re-captioning of the data to disguise the mistake at the final state. In addition, there was some significant under-counting of the deaths of children - our earlier work on the camp records and death notices ${ }^{[18]}$ as compared with the NGK dominee registers suggests the largest under-count was of the very young, of stillborn babies and infants and children not yet baptised. If Goldman had used the British concentration camp records - and we must emphasise that by this we mean all the records, that is, including the returns and death notes and all the other routine daily or weekly transfers of information, and not just the registers than many researchers are obsessed by - as his base, rather than the plethora of 'het volk' sources, this would have included the expunged children and the omitted adults. The result would have been a larger, we think significantly larger, final count specifically for those camps where full returns as well as registers exist, not least because it would have included the black people who lived and worked in what were referred to as white camps, but which actually had mixed racially populations. ${ }^{[19]}$

5.2 There is also an irony involved which certainly would not have been lost on Botha, Steyn and the other political leaders promoting their different versions of the enumerative and commemorative project. The proto-nationalist movement which Goldman served was an incorporationist one that sought to harness the many disagreeing elements of the population of Boer, later Afrikaner, people in South Africa into 'het volk', a people (seemingly) single and indivisible. ${ }^{[20]}$ Those differences had been writ large over the course of the South African War and were majorly reflected in the populations of the concentration camps, which were composed by British supporters and those who were neutral and just wanted the war to end, as well as determined Republicans (Spies [1977] 2001, Grundlingh [1979] 2006). Given that all the camps had politically diverse populations, the dead volk who were enumerated and commemorated actually included the many dissenters from the Republican cause. In death and by a retrospective enumerative and commemorative move, those who died were incorporated wholesale into 'the folk', and thereby many of them became part of the proto-nationalism they had in life not supported, or more strongly had opposed.

5.3 An interesting exchange took place between November 1912 and January 1913, when Goldman was still working on his lists and counts, with Mrs Steyn (herself a key figure in the post-war women's organisations and in publishing women's testimonies) acting as an amanuensis for her partially paralysed husband, ex-President Steyn of the Free State. These letters indicate a further complexity of the process and the 'for practical purposes', rather than 'with absolute accuracy', character of the numbers being produced. The first Steyn letter of 3 November 1912 (RS7: f76) requests numerical information. The second of 28 November 1912 (RS7: f77) acknowledges receipt of information from Goldman but asks about its source, demonstrates that Goldman's response to the first letter had requested information about the women and children in the Free State camps, and indicates that Goldman derived his interpretation of what 'age 16' meant from ex-President Steyn. The third, dated 6 January 1913 (RS7: ff78-79) ${ }^{[21]}$, is quite momentous in stating that: 
"... Those who thus died in the concentration camps children 22,257 - women - $8288-$

young women $-825-$ Total $-26,370-$

If you find this correct then it will appear on the Monument (at the back)

The National Monument is to the memory of the 26,370 women and children who died in the

concentration camps and elsewhere in other ways because of the war. You will see no

mention is made of the men because it is a women's monument. ..."

5.4 As well as omitting the deaths of 'men' (that is, those over the age that Steyn, and by this time Goldman, were taking as the marker of who was and was not a child), this third Steyn letter differentiates between 'young women' and women, perhaps because of awareness that the age of 12 had been used as the marker in the Free State camps, so this may have been those between age 13 and 16 up to the seventeenth birthday. It also, notably, makes a significant mistake in addition: $22,257+8,288+825$ actually equals 31,370 and not 26,370 . What appears on the Vrouemonument dedication, however, is the number' as erroneously added up in this Steyn letter - 26,370 - and not the 'accurate' number that Goldman later arrived at [Vrouemonument and inscription]. And of course, even if the Steyn addition had been the correct one, 'the number' arrived would have been even more different from Goldman's.

5.5 Is the difference a matter of 'the men' and their absence from or presence in the number? Certainly references to Goldman's 'the number' list the number of deaths of women and children and of 'men' separately, as in the following, written fifty years apart:

"The deaths there [in the camps] of 26,251 women and children together with 1,676 men over 16 - mostly greybeards - softened the resistance of the Boers in the field. (Otto 1954: $170)^{[22]}$

"After the war P L A Goldman officially determined that 27927 women, children and men died in the camps. Of the 26251 women and children 22000 were under the age of sixteen and of the 1676 men over the age of sixteen 1421 were elderly" (Jacobs 2003: 17)

5.6 However, the difference cannot be explained by this - the numbers still just 'do not add up'. There are two more likely explanations. It is possible that 'the Steyn (and thus the Vrouemonument) number' when correctly added to 31,370 is a late 1912/early 1913 incarnation of Goldman's numbers which were by December 1913 considerably revised. It is also possible that these Steyn numbers were compiled through a process similar to, but separate from, the one Goldman presided over, and thus the far greater extensiveness of the Free State field-cornet enumerations in the RS Goldman collection.

5.7 Unfortunately, the records of the Steyn Vroumonument committee were lost when the law office of its secretary closed or moved early in the twentieth century and have never been located, ${ }^{[23]}$ so there is no documentary means of investigating this latter possibility. The jury remains out here, and what stands is the 'incorrect' number inscribed on the Vrouemonument, and the different 'for practical purposes, sort of accurate' number produced by Goldman. However, in a political sense Steyn and the Women's Monument had scooped the pool, for the number repeated and repeated is that on the face of the Vrouemonument, with the monument itself seen to encapsulate the factual meaning of the 26,370 inscribed on it.

\section{On standard and superior stories}

6.1 Numbers bear repetition as seemingly factual statements representing in symbolic form the 'real things' that these are the numbers of. However, numbers are not inert and invariant - 1939, for instance, 'contains' very different things for a European who lived through this year and someone born in the 1970s or 80s, and for a Czech and US citizen; and an equation has different resonance for a mathematician and someone who is innumerate. Also, as with the 1939 example, some numbers are seen to hold the story of their meaning, to summarise and encapsulate this.

6.2 But what kind of a story does 'the number' have in relation to Goldman's investigation? What does our case study indicate about this? In Tilly's (1994: 268-9) terms, Goldman's number is the product of a superior story and fits most of the characteristics Tilly assigns to such. Within the limitations we discussed earlier, Goldman attempted to be precise, consistent and accurate. His procedures, methodological framework and working method included all the major actors that producing a valid account required. His investigation represented cause-and-effect relations that were not directly visible in the accounts utilised. It connected the story with wider times, places and social actors, and it worked from direct causes to indirect and more incremental structural ones. In the circumstances, recognising the actually imprecise data that existed, and given Goldman's political views, his is a creditable if imperfect piece of work. By contrast, the number on the Vrouemonument appears almost without antecedents; its lineage is uncertain; its repetition lacks substantial traceable foundation; and it is in its own terms incorrect because, behind its face, its composing elements were added up wrongly. It has the characteristics Tilly assigns to standard stories. However, over time it is the Vrouemonument that is hugely resonant (Grundlingh 2002) and Goldman's the number' that has become mute.

6.3 Clearly, many stories of lives disrupted and concerning the deaths of family and friends were represented in the enumerations told to the field-cornets and predikants and summarised and sent to 
Goldman, and in the camp registers and returns recording people's arrivals, sicknesses and deaths he also received. These were, perhaps not in their telling but certainly in their recording, standard stories. Number also bears repetition in this other sense, then. There was a common wartime experience, at least in its outward forms, but in their specificities these were what C. Wright Mills (1959) refers to as 'personal troubles', happening to particular people in specific places and definite times and having their own distinctive resonance, suffering and pain. However, these were transmuted, both at the time and subsequently, into general shared 'public issues'. Mills characterises this as a growing awareness of the larger historical scene and that seemingly 'personal' troubles transcend local environments and circumstances, involving a debate or discourse at a public level about contradictions and antagonisms in relation to what he calls 'institutional arrangements'. In part Goldman's investigation was a product, in part a contributor, together with the Monument Committees, the Ecclesiastical Commission, the Vrouemonument Committee, the women's organisations, cultural brokers and published testimonies, to this emergent sense of the larger meaning of such matters for 'the people' and its history, for the Afrikaner volk.

6.4 Stories are told, the past and near-present are therein recounted, and their schematic organisation of 'the people' and 'the facts' are passed on in such tellings. So-called standard stories gain power from their clarities in structure, content and implicit or explicit claims. And over time, as listeners and tellers alike come to have no connection with, let alone direct knowledge of, the story's events and characters, such retellings can take on the perceived disposition, less of stories than of statements about known and passed on facts. This most certainly happened with the concentration camps of the South African War and the deaths occurring in them, but less by means of 'the number' as produced by Goldman, and more by virtue of the symbolic import that the Vrouemonument came to have because of the standard storied framework it was located within and seen as the culmination of. This is not least because the sculptor Anton von Vouw's statue of a woman and dying child and the accompanying bas reliefs on either side of the monument literally 'tell' powerfully visible stories about the deaths which occurred.

6.5 Thinking about standard stories in general, and that represented by the Vrouemonument in particular, there are interesting clues as to why Goldman's 'the number', and the number as represented by the monument, have had such different political and social afterlives. In a literal as well as figurative sense, the storied nature of Goldman's 'the number' is buried: while the many thousands of enumerated deaths certainly provided an extensive foundation for his 'one accurate statistic', these enumerations were at the time organisational detritus and are now buried aspects of a detailed working process, and their storied character was never in itself seen as central or valorised to what he was doing. The dedication on the Vrouemonument, by immense contrast, immediately links the private troubles of individual women's and children's deaths with the public issue that the Vrouemonument pointedly insists upon and that its '26,370' signifies. Moreover, what appears on the Vrouemonument was underpinned and surrounded by a plethora of stories, the stories of the many women's testimonies which were told and re-told, also standard stories, but seemingly overwhelming in their numbers and constantly over time retold and repeated. The polemicist in Tilly insists on the simplicities of standard stories, but at the same time he insightfully recognises that people routinely link judgements, ideas about what is likely or plausible in the circumstances, and causal explanations, and all of which surface within the frame of story-telling and retelling (Tilly 1999: 265-6; see also Eden 2006, 2008). This is precisely what the visibility of the storied character of the Vrouemonument, in contrast to the stark anonymity of Goldman's 'the number', enables. ${ }^{[24]}$

6.6 Is there another research story here, and is our case study a means of supplying a would-be superior story? As our comments about standard stories and the power of the Vrouemonument will have indicated, we find Tilly's binary standard v. superior emphasis far too limited. He does, however, mark out an inbetween role for historical sociology, in 'identifying the social situations in which certain types of stories arise and tracing the consequences of adopting those stories rather than others that are, in principle, available... analyzing the processes by which people actually create, adopt, negotiate, and alter the stories they employ in routine social life' (Tilly 1999: 269-70). Eschewing fixed notions of standard and superior, and working as historical sociologists in the way Tilly recommends, we have shown just how important these processes can be and just how powerful a hold they can gain over future thinking. Tilly's (1984) Big Structures... is a riposte to the 'pernicious postulates' inherited from nineteenth century modes of thinking, which he argues inhibit contemporary social science. While we agree with him, for us the weight of received fact more generally has a far more pernicious on free thinking. Better, we think, the condescension of posterity and social science, than deference and the assignment of epistemological privilege to the past; and contextualising its stories helps social scientists gain some analytic purchase on which of these accounts of the past are warranted - and which of them just do not add up.

\section{Acknowledgements}

Our thanks to the National Archives Repository in Pretoria for assistance over many periods of archival fieldwork and for permission to take jpegs of documents therein. We are extremely grateful to Elizabeth van Heyningen for her generosity in sharing work on the RS Goldman collection and her helpful comments on this present paper. It is always a great pleasure to discuss and debate with her. Liz Stanley would like to thank the University of Pretoria and its Sociology Department for a Visiting Professorship during which her contribution to this article was carried out. Particular thanks are due to Professor Janis Grobbelaar, her staff and research students at all levels, and especially the stupendous Mev Martie Hanekom. Helen Dampier gratefully acknowledges the British Academy Small Research Grant which enabled her to carry out part of the research for this article. This research came about as a by-product of the Olive Schreiner Letters Project (http://www.oliveschreinerletters.ed.ac.uk) and our grateful thanks are due to the UK's Economic and Social Research Council (ESRC), whose generous support we would like to acknowledge (RES 062-23-1286). 
${ }^{1}$ These were camps for Boer supporters of Britain, for refugees from the fighting, and then in the commando phase of the war for farming populations removed from their land. The high number of deaths occurring was due to epidemics, in particular of typhoid, measles and the sequelae of the latter, which swept the camps and equally impacted on British (but not Boer) troops. Goebbels, a close associate of South African nationalists at German universities in the later 1930s, deliberately called the Nazi work and death camps concentration camps, as part of anti-British propaganda by the National Socialists. See Spies 1977, Grundlingh [1979] 2006, Dampier 2005, Stanley and Dampier 2005, Stanley 2006, Wilkins \& Strydom 1978.

2 Boer proto-nationalism preceded full-blown Afrikaner nationalism and took predominantly cultural forms in which women were highly active as cultural brokers as well as consumers. Te post-war mushrooming of women's organisations extremely important in this, as was their solicitation, publication and distribution of women's testimonies about their wartime experiences. See Vincent 1999, Du Toit 2003, Stanley 2002, 2006, Dampier 2005, Stanley and Dampier 2006, 2007.

${ }^{3}$ Van Heyningen proposes that Botha was concerned with healing the rifts in the Afrikaner community and that Goldman's project was actually about a common grieving, and so she questions whether it was nationalist in the way we propose (Personal communication, September 2009). We disagree - nationalism should not be a term reserved slely for 'bad' things that academics disagree with, and clearly protonationalism was part and parcel of both Goldman's work and Botha's wider project, as our wider work on proto-nationalism referenced elsewhere in this article fully confirms. See also Footnote 16.

${ }^{4}$ Waves of women's testimonial writings were published and circulated immediately after 1902, around 1910-1913, in the mid 1920s, the later 30s, and the later 1940s, all important junctures for the nationalist cause. By the 1940s, knowledge of the 'special pleading' highly partial character of such writings was lost and they were increasingly treated as factual accounts about the past produced by those with first-hand experience and no particular political axe to grind. These were, through their repetitious character, shared simplified structure, stock characters and plots, standard stories or perhaps variants on a core standard story, in Tilly's terms. However, as an early commentator (Hobhouse 1927) noted, what was initially suspiciously similar, through the constancy of repetition later seemed to have the qualities of veracity and facticity for popular audiences who were not 'in the know'. (See Stanley 2002, 2006, Dampier 2005, Stanley and Dampier 2006, 2007).

${ }^{5}$ Arthur Davey was also responsible for archiving the collection, and he largely did this without changing the organisation of the material as the archive received it, although he certainly interleaved additional materials, as the Inventory explains (Personal communication from Elizabeth van Heyningen, whose husband was Davey, September 2009).

${ }^{6}$ The jpegs provided obviously are of the original documents and show the language these were written in.

7 The full title is: 'Inventaris argief van die amptenaar belas met die insameling van gegewens van sterfgevalle onder die Republikeinse strydmagte en burgerlike bevolking 1899-1902'.

${ }^{8}$ These are the Nederduits Gereformeerde Kerk or Dutch Reform Church (the largest in the Free State and often having played a pastoral role in the concentration camps), the Nederduitse Hervormde of Gereformeerde Kerk or Dutch Reformed Church (the largest in the Transvaal), and the Gereformeerde Kerk (small and concentrated in particular areas such as the Potchefstroom and Middelburg areas of the Transvaal and Reddersburg in the Free State), which broke away from the NHK in 1859. For the enumerative purposes discussed here, it seems that the GK was re-associated with the NHK although not without dissention, as enumeration forms were often printed with the heading Nederduitse Hervormde of Gereformeerde Kerk, but with parts of this variously crossed out by different enumerators.

\section{${ }^{9}$ See Footnote 3.}

${ }^{10}$ For example, see T1: 5, Publikasies (Publications) regarding a 1908 report about a Middelburg monument and the work of the Eberhaezer Monument Comite in establishing this. On the importance of these cultural developments see Hofmeyr 1987, Sparks 1991, Le May 1995, Stanley and Dampier 2007.

11 Steyn's plan for the Vrouemonument and the events it represented caught a public nerve, with many thousands of small donations received from all four provinces and all sections of the white population in South Africa.

12 The Veldkornets were part of the combined political, judicial and commando structure of the Boer Republics, had jurisdiction over districts or part-districts and were responsible to higher coordinating level Commandants.

${ }^{13}$ We conclude this from the absence of material from this source in the Volumes, and so the comment is necessarily tentative.

14 Transvaal examples here concern the Huyser (A951) and Preller (A787) collections in the Transvaal Archives, Pretoria.

15 Van Heyningen helpfully reminds us (Personal communication, September 2009) that this is documented in a telegram from Milner to Chamberlain of 4 December 1901 (CO 879/73, 636 National 
Archives, Kew, UK); our thanks for this information.

${ }^{16}$ This is a general example used by Van Heyningen

(http://www.lib.uct.ac.za/mss/bccd/obccd/pub_view.php?pg=info), but a specific one which we tracked in our work on RS Goldman. A similar point is made by Van Heyningen in relation to the multiple appearances of Janetta Gesina Johanna Wilhelmina Bernado, who died in Bloemfontein camp hospital but was actually never in Bloemfontein camp (Personal communication, September 2009).

17 Van Heyningen disagrees with our 'he did the best that was possible in the circumstances and with his lack of training and political viewpoint' overall assessment of Goldman's working methods, and she assesses what he did as amateur and not verifiable (Personal communication, September 2009). Our view is that, at the time, a 'professional' approach in today's terms was not available to Goldman; and anyway we are clear that no attempt to produce the number' is fully verifiable because no full accurate data exists to be used to supply this, although we note with interest Van Heyningen's attempts to get around this (http://www.lib.uct.ac.za/mss/bccd/index.php). Having an appreciation of the problems Goldman had to deal with, and an interest in how he responded to them, most certainly does not mean we think his aim 'the number' - was achievable. With respect, we come to a similar conclusion about Van Heyningen's attempt to produce 'the number', for it uses the same partial data, endeavours to clean it up more, professionalises its presentation and discussion, and struggles to correlate material, but it does so (as Goldman did) using different and what are at basis incommensurable sources.

18 See Stanley and Dampier 2005, Stanley 2006.

19 Black people who died in the 'white' camps were excluded from Goldman's count, in spite of many of these deaths being recorded in the British concentration camp records; indeed, his exclusions are in some cases highly visible because he wrote their ethic groupings (Maketee, Bushman and so on) onto hospital and registers he worked on. However, the removal of black people from the commemoration process was not entirely consistent, with some black people with 'white' Afrikaans surnames included on camp memorials, including the Buys people at Pietersberg and the Habels at Turffontein. See Stanley 2006, Chapter 7.

20 See Grundlingh 2006 [1979], especially Chapters 8, 9 and 10. Grundlingh sees a general unity emerging through a nationalist political process across the annexed Republics, while we emphasise the continuance of disagreements between the nationalist parties, and particularly those heading them, in the Transvaal and the Free State. These were rooted in the Transvaal's sometimes less than fully honourable treatment of the Free State, but also between the conciliationist Botha and Smuts, and the hardline 'bitter-enders' of Steyn and his close political allies. See also Footnote 3.

21 "Wy hebben dus als gestorven in de Koncentratie Kampen - kinderen 22,257 - Vrouwen 8288 jongedochters 825 - Totaal 26,370 - Als u dit korrecht vind dan zal op Monument komt te staan (achter op)". Het Nasionaal Monument opgericht ter gedachtenis van de 26,870 vrouwen en kinderen die in de Koncentratie Kampen en de andere die elders ten gevolge van den oorlog zyn omgekomen. $U$ zal zien er word geen melding van de mans gemaacht daar het een Vrouwe Monument is..."

22"Die afsterwe aldaar van 26,251 vroue en kinders benewens 1,676 mans bokant 16 jaar - meestal grysaards - het die weerstand van die Boere in die veld vermurwe."

23 Personal Communication with Elria Wessels, then archivist at the War Museum of the Boer Republics, Bloemfontein, July 2004.

${ }^{24}$ This is to remain within the context of South Africa and the period up to the 1940 s. 'The number' - that is, the Vrouemonuent and its number - has continued over the time since then to accrue public meaning around repetitions and reinterpretations, the most powerful of which involved the strategy under apartheid to legitimate Afrikaner nationalism and racism by reference both to the past history of the concentration camp deaths, and also and increasingly by reference to viewing the number' as inscribed on the Vrouemonument as 'a story of the facts' in and of itself. This has been supported by the huge comparison that has been made through repetitions of the words 'concentration camps', which by their post-Nazi meaning and power seem to have explanatory power in association with 'the number' of a 'it was genocide' kind by claiming tacit kindred between these deaths and the six million in the Nazi camps. One extreme example of this kind claims, "The concentration camps of the South African War arguably laid down a template for civilian suffering that subsequently the Herero of German South West Africa, the Jews of Europe, the Russians under Stalin, the Cambodians under Pol Pot and most recently the civilians in Rwanda and in all parts of the former Yugoslavia have endured" (De Reuck 1999: 73).

\section{References}

\section{(a) Archive references}

National Archives Repository (1959) "The inventory of the official charged with collection of statistics of deaths in the Republican forces and amongst civilians 1889-1902" RS Goldman. Pretoria: National Archives Repository. 


\section{(b) Articles, books and chapters}

DAMPIER, Helen (2005a) "Women's Testimonies of the Concentration Camps of the South African War: 1899-1902 and After" (Unpublished PhD thesis, University of Newcastle)

DAMPIER, Helen (2005b) "Everyday Life' in Boer Women's Testimonies of the Concentration Camps of the South African War, 1899-1902" in (eds) Graeme Dunstall and Barry Godfrey Crime and Empire 1840-1940: Criminal Justice in Local and Global Context Cullompton, Devon: Willan Publishing.

DAMPIER, Helen (2007) "Review of A.D.L. Chaplain in the Concentration Camp, Bethulie, O.R.C, 1901 Woman's Endurance" Historia 52(1).

DAMPIER, Helen (2008) "Re-reading as methodology: the case of Boer women's testimonies" Qualitative Research 8, 3, 367-377. [doi:10.1177/1468794106093633]

DAMPIER, Helen \& Liz Stanley (2008) "Parallel narratives: Photographs in Boer women's wartime testimonies" in (eds) David Robinson et al Narratives and Fiction Huddersfield, UK: University of Huddersfield Press.

DE REUCK, Jenny (1999) "Social Suffering and the Politics of Pain: Observations on the Concentration Camps in the Anglo-Boer War 1899-1902" English in Africa 26, 2, 69-88

DU TOIT, Marijke (2003) "The Domesticity of Afrikaner Nationalism: Volksmoeders and the ACVV, 19041929" Journal of Southern African Studies 29, 1, 155-176 [doi:10.1080/0305707032000060485]

EDEN, Lyn (2006) "Why? Charles Tilly's cabinet of wonders" Qualitative Sociology 29: 551-5. [doi:10.1007/s11133-006-9044-7]

EDEN, Lynn (2008) "Tilly's trouble with stories: the narrator and the case of the missing disposition" Paper given at the conference 'Contention, Change, and Explanation: A Conference in Honour of Charles Tilly' New York: Social Science Research. Council

<http://www.ssrc.org/hirschman/content/2008/texts/Eden.pdf>

Garfinkel, Harold (1967) "Good organizational reasons for bad organizational records" in his Studies in Ethnomethodology New Jersey: Prentice-Hall: 186-207.

GRUNDLINGH, Albert (1979) Die 'Hendsoppers' en 'Joiners': Die Rasionaal en Verskynsel van Verraad Kaapstad en Pretoria: Hollandsch Afrikaansche Uitgevers Maatschappij (H.A.U.M.)

GRUNDLINGH, Albert [2006] The Dynamics of Treason: Boer Collaboration in the South African War of 1899-1902 Pretoria: Protea Book House

GRUNDLINGH, Albert "The National Women's Monument: the making and mutation of meaning in Afrikaner memory of the South African War" in (eds) Greg Cuthbertson, Albert Grundlingh \& Mary-Lynn Suttie Writing a Wider War: Rethinking Gender, Race and Iderntity in the South African War, 1899-1902 Athens, USA, Ohio University Press, pp.18-36.

HOBHOUSE, Emily (1902) The Brunt of the War and Where It Fell London: Methuen \& Co.

HOBHOUSE, Emily (1927) War Without Glamour. Women's War Experiences Written By Themselves, 1899-1902 Bloemfontein: Nasionale Pers Beperk

HOFMEYR, Isabel (1987) "Building a Nation From Words: Afrikaans Language, Literature and Ethnic Identity, 1902-1924" in Shula Marks and Stanley Trapido (eds) The Politics of Race, Class and Nationalism in Twentieth Century South Africa London \& New York: Longman, 95-123

LE MAY, G. H. L (1995) The Afrikaners: An Historical Interpretation Oxford: Blackwell Publishers Ltd.

CHANGUIO, Louise; Frik Jacobs and Paul Alberts (2003) Suffering of War: A Photographic Portrayal of the Suffering in the Anglo-Boer War Bloemfontein: Kraal Publishers for the War Museum of the Boer Republics

MILLS, C. Wright (1959) The Sociological Imagination London: Oxford University Press

OTTO, J.C. (1954) Die Konsentrasiekampe Kaapstad, Bloemfontein, Johannesburg: Nasionale Boekhandel, Beperk

SPARKS, Allister (1991) The Mind of South Africa London: Mandarin

SPIES, S.B (1977) Methods of Barbarism: Roberts and Kitchener and Civilians in the Boer Republics, January 1900 - May 1902 Cape Town: Human \& Rousseau

STANLEY, Liz (2002a) "A 'secret history' of local mourning: the South African War, the Vrouemonument and state commemoration" Society in Transition: Journal of the South African Sociological Association 19, $1-22$.

STANLEY, Liz (2002b) "Mourning becomes...: the work of feminism in the spaces between lives lived and lives written" Women's Studies International Forum 25, pp.1-17. [doi:10.1016/S0277-5395(02)00219-4] 
STANLEY, Liz (2002a) "Women's South African War Testimonies: Remembering and Forgetting 'Slant-wise' the Racial order" Tydskrif vir Nederlands en Afrikaans (TN\&A) 7, 93-118

STANLEY, Liz (2005) "Emily Hobhouse, moral life and the concentration camps of the South African War, 1899-1902" South African Historical Journal 52, pp. 60-81. [doi:10.1080/02582470509464864]

STANLEY, Liz (2006) Mourning Becomes... Post/Memory and the Concentration Camps of the South African War Manchester: Manchester University Press

STANLEY, Liz and Helen Dampier (2005) "Aftermaths: Post/memory, Commemoration and the Concentration Camps of the South African War 1899-1902" European Review of History 12, 1, 89-113

STANLEY, Liz and Helen Dampier (2006a) "Simulacrum diaries: Time, the 'moment of writing' and the diaries of Johanna Brandt-Van Warmelo" Life Writing 3, 2, 25-52

STANLEY, Liz and Helen Dampier (2006b) "Knowledge, the 'moment of writing' and the simulacrum diaries of Johanna Brandt-Van Warmelo" in (eds) Kate Milnes et al Narrative, Memory and Knowledge Huddersfield, UK: University of Huddersfield Press.

STANLEY, Liz and Helen Dampier (2007) "Cultural Entrepreneurs, Proto-Nationalism and Women's Testimony Writings: From the South African War to 1940" Journal of Southern African Studies 33, 3, 501519 [doi:10.1080/03057070701475278]

STANLEY, Liz \& Sue Wise (2006) "Putting it into practice: Using feminist fractured foundationalism in researching children in the concentration camps of the South African War" Sociological Research Online $11,1<$ http://www. socresonline.org.uk/11/1/stanley.html> (awarded the 2007 Sage Prize for Innovation \& Excellence)

THOMPSON, Edward (1968) The Making of the English Working Class Harmondsworth: Penguin.

TILLY, Charles (1984) Big Structures, Large Processes, Huge Comparisons New York: Russell Sage Foundation.

TILLY, Charles (1999) "The trouble with stories" in (eds) R. Aminzade \& B. Pescosolido The Social Worlds of Higher Education Thousand Oaks, USA: Pine Forge Press: 256-70.

TILLY, Charles (2003) Stories, Identities, and Political Change New York: Rowman \& Littlefield Publishers, Inc.

VINCENT, Louise (1999) "The Power Behind the Scenes: The Afrikaner Nationalist Women's Parties, 1915 to 1931" South African Historical Journal 40, 51-73. [doi:10.1080/02582479908671348]

WILKINS, Ivor \& Hans Strydom (1978) The Super-Afrikaners Johannesburg: Jonathan Ball Publishers. 